\title{
Preliminary study of the microbial spectrum of the digestive tract in broilers fed diets with and without antibiotic supplementation
}

\author{
F. Brzóska ${ }^{1,4}$, S.B. Buluchevskij ${ }^{2}$, B. Śliwiński ${ }^{1}$ and K. Stecka ${ }^{3}$ \\ ${ }^{1}$ National Research Institute of Animal Production, \\ Department of Animal Nutrition and Feed Science \\ 32-083 Balice, Poland \\ ${ }^{2}$ National Scientific Research Institute of Feeds, Moscow, Russia \\ ${ }^{3}$ Institute of Agriculture and Biotechnology, Warsaw, Poland
}

\begin{abstract}
The predominant bacteria in the small intestine of broilers were Lactobacillus spp., Escherichia coli and Streptococcus spp. Compared with the antibiotic-supplemented group, experimental groups receiving mannan oligosaccharide, lactic acid bacteria, and organic acids contained more Enterococcus spp., Escherichia coli, Streptococcus spp. in the intestinal content. The predominant bacteria in the caecum were Escherichia coli, Lactobacillus spp. and Enterococcus spp. Unlike the other groups, no Clostridium spp. bacteria were found in the caecum of birds receiving antibiotic supplements. There was no effect of the type of acid (fumaric vs formic) in feed on the composition of intestinal microflora of chickens.
\end{abstract}

KEY WORDS: broiler chicken, ileum, caecum, antibiotic, microbial spectrum

\section{INTRODUCTION}

The composition of intestinal microflora is influenced by the presence of bacteria, moulds, and yeast in feed and by the feed's particle size and physical form (Engberg et al., 2002; Knarrenborg et al., 2002). The planned ban on the therapeutic use of antibiotics in poultry nutrition has led researchers to look for substances that protect the digestive tract of birds against pathogenic bacteria (Verstegen and Williams, 2002).

The objective of this study was to determine the effects of mannan oligosaccharide, lactic acid bacteria, fumaric acid and formic acid given in feed on the microflora composition of the small intestine and caecum of broiler chickens.

\footnotetext{
${ }^{4}$ Corresponding author: e-mail: fbrzoska@izoo.krakow.pl
} 


\section{MATERIAL AND METHODS}

The composition of intestinal microflora was compared in 5-week-old ROSS broiler chickens fed diets with (ANT) and without (CON) antibiotic supplementation, and with supplemental mannan oligosaccharide (MO), lactic acid bacteria (LAB) and feed acidifiers in the form of fumaric acid (FUM) or formic acid (FOR). The broilers were fed a maize, wheat and soyabean meal diet supplemented with $0.5 \%$ premixes (BASF Kutno, Poland). The antibiotic feed contained flavofosfolipol $(5 \mathrm{mg} / \mathrm{kg})$, while the experimental feed contained mannan oligosaccharide $(1 \mathrm{~g} / \mathrm{kg})$, lactic acid bacteria and fumaric acid $(9.7 \mathrm{~g} / \mathrm{kg})$ or formic acid $(11.8 \mathrm{~g} / \mathrm{kg})$. The bacteria originated from the Institute of Agricultue and Biotechnology in Warsaw. These were Lactobacillus paracasei KKP 824, Lactobacillus rhamnosus KKP 825, and Lactobacillus rhamnosus KKP 826 with an activity of $6.7 \times 10^{8}$ c.f.u./g, mixed at a 1:2:2 ratio, 3 million bacterial cells/ bird/day. Intestinal microflora was studied in 5 birds randomly selected from 160 birds of each group. Samples from the small intestine and caecum were taken for analysis under anaerobic conditions into sterile tubes and immediately brought to a laboratory. Analyses were performed at the Department of Clinical Microbiology of the Jagiellonian University Collegium Medicum Children's Hospital, following internal procedures.

\section{RESULTS}

The predominant bacteria in the small intestine were Lactobacillus spp. in all groups of birds (Table 1). Escherichia coli and Streptococcus spp. were 10 times less common. Traces of bacteria (Clostridium spp., Staphylococcus spp., Enterococcus spp. and Bacillus spp.) were found in the small intestine. The experimental groups contained more Enterococcus spp., Escherichia coli, Streptococcus spp. in the intestinal content. In chickens of both experimental groups, there were traces of Staphylococcus aureus, Proteus mirabilis and Klebsiella pneumonia. The dominant bacteria in the caecum were Escherichia coli, Lactobacillus spp. and Enterococcus spp. (Table 2). The concentration of Escherichia coli in the caecum was 100-fold higher on average than in the small intestine, and that of Lactobacillus spp. 10 times lower than in the small intestine. In the caecum, Enterococcus spp. bacteria were 10 times more numerous than in the small intestine. In all groups of birds, traces of Bacillus spp. were found in the intestines. The dietary antibiotic supplement eliminated Clostridium spp., including Clostridium perfringens, from the caecum. Acid type (fumaric vs formic) had no effect on the microflora composition of the chickens. 


\section{DISCUSSION}

Table 1 . The intestinal flora in chickens aged 5 weeks

\begin{tabular}{lcccc}
\hline & \multirow{2}{*}{$\begin{array}{c}\text { Without } \\
\text { Species of microflora }\end{array}$} & $\begin{array}{c}\text { With } \\
\text { antibiotic }\end{array}$ & antibiotic & \multicolumn{2}{c}{ MO plus LAB } \\
\cline { 5 - 5 } & (CON) & (ANT) & fumaric & formic \\
& $+++5 / 5$ & $+++5 / 5$ & $+++5 / 5$ & $+++5 / 5$ \\
Lactobacillus spp. & $+1 / 5$ & negative & negative & negative \\
Clostridium spp. & negative & negative & negative & $+1 / 5$ \\
Clostridium perfringens & $+2 / 5$ & $+1 / 5$ & $+3 / 5$ & $+3 / 5$ \\
Enterococcus spp. & $+3 / 5$ & $+4 / 5$ & $+5 / 5$ & $++4 / 5$ \\
Escherichia coli & negative & negative & $+1 / 5$ & negative \\
Escherichia fergussoni & negative & $+1 / 5$ & $+2 / 5$ & $+1 / 5$ \\
Bacillus spp. & $+4 / 5$ & $+2 / 5$ & $++2 / 5$ & $+4 / 5$ \\
Streptococcus spp. & $+1 / 5$ & $+2 / 5$ & negative & $+2 / 5$ \\
Staphylococcus spp. & $+1 / 5$ & negative & $+1 / 5$ & $+1 / 5$ \\
Staphylococcus aureus & negative & negative & negative & negative \\
Staphylococcus epidermis & negative & $++4 / 5$ & negative & negative \\
Campylobacter spp. & negative & negative & negative & negative \\
Salmonella spp. & negative & negative & negative & negative \\
Shigella spp. & negative & negative & negative & negative \\
Corynebacterium spp. & negative & negative & $+1 / 5$ & $+1 / 5$ \\
Proteus mirabilis & $+1 / 5$ & negative & $+1 / 5$ & negative \\
Klebsiella pneumonia & $+1 / 5$ & negative & negative & negative \\
Klebsiella oxytoca & & & & \\
\hline
\end{tabular}

MO mannan oligosaccharide

LAB lactic acid bacteria

$+\quad$ to $100 \mathrm{cfu}$

+ to $1000 \mathrm{cfu}$

+++ more than $1000 \mathrm{cfu}$

$1 / 5-5 / 5$ present in this number of birds/total number of birds tested

Table 2. The caecum flora in chickens aged 5 weeks

\begin{tabular}{|c|c|c|c|c|}
\hline \multirow[b]{2}{*}{ Species of microflora } & \multirow{2}{*}{$\begin{array}{l}\text { Without } \\
\text { antibiotic } \\
(\mathrm{CON})\end{array}$} & \multirow{2}{*}{$\begin{array}{c}\text { With } \\
\text { antibiotic } \\
(\mathrm{ANT})\end{array}$} & \multicolumn{2}{|c|}{ MO plus LAB ${ }^{1}$} \\
\hline & & & $\begin{array}{c}\text { fumaric } \\
\text { acid (FUM) }\end{array}$ & $\begin{array}{c}\text { formic } \\
\text { acid (FOR) }\end{array}$ \\
\hline Lactobacillus spp. & $++5 / 5$ & $++5 / 5$ & $++5 / 5$ & $++5 / 5$ \\
\hline Clostridium spp. & negative & negative & $+3 / 5$ & negative \\
\hline Clostridium perfringens & negative & negative & $+3 / 5$ & $+3 / 5$ \\
\hline Enterococcus spp. & $+3 / 5$ & $+4 / 5$ & $++5 / 5$ & $+4 / 5$ \\
\hline Escherichia coli & $+++5 / 5$ & $+++5 / 5$ & $+++5 / 5$ & $+++5 / 5$ \\
\hline Bacillus spp. & $+1 / 5$ & $+2 / 5$ & $+1 / 5$ & $+1 / 5$ \\
\hline Streptococcus spp. & $+4 / 5$ & $+4 / 5$ & negative & negative \\
\hline Staphylococcus epidermis & $+2 / 5$ & $+1 / 5$ & negative & $+2 / 5$ \\
\hline Campylobacter spp. & negative & negative & negative & negative \\
\hline Salmonella spp. & negative & negative & negative & negative \\
\hline Shigella spp. & negative & negative & negative & negative \\
\hline Corynebacterium spp. & $+1 / 5$ & negative & negative & negative \\
\hline
\end{tabular}

\footnotetext{
${ }^{1}$ for abbreviations see Table 1
} 
The present results indicate that Lactobacillus spp. bacteria are predominant in the small intestine of broilers aged 5 weeks, while the type of supplement (including antibiotic) or its absence does not influence the presence of these bacteria. Withdrawal of the antibiotic from chicken diets increases the count of Streptococcus spp., Staphylococcus spp., and Proteus mirabilis in the small intestine. The content of Lactobacillus spp. in the caecum is the same regardless of the type of supplement (including the type of organic acid) used as a feed acidifier. Clostridium spp., including $\mathrm{Cl}$. perfringens bacteria were found in the caecum of chickens receiving mannan oligosaccharide, lactic acid bacteria and organic acids, unlike in chickens receiving the feed antibiotic.

\section{CONCLUSIONS}

The replacement of an antibiotic with mannan oligosaccharide and lactic acid bacteria, and acidification of feed with fumaric or formic acid does not reduce Lactobacillus spp. and Escherichia coli in the digestive tract of broiler chickens. Intestinal microflora of the chickens is not differentiated by fumaric and formic acid used to acidify feeds in the presence of mannan oligosaccharide and lactic acid bacteria.

\section{REFERENCES}

Engberg R.M., Hedemann M.S., Jensen B.B., 2002. The influence of grinding and pelleting of feed on the microbial composition and activity in the digestive tract of broiler chickens. Brit. Poultry Sci. 43, 569-579

Knarreborg A., Simon M.A., Enberg R.M., Jensen B.B., Tannock G.W., 2002. Effects of dietary fat source and subtherapeutic levels of antibiotic on the bacterial community in the ileum of broiler chickens at various ages. Appl. Environ. Microbiol. 68, 5918-5924

Verstegen M.W.A., Williams B.A., 2002. Alternatives to the use of antibiotics as growth promoters for monogastric animals. Anim. Biochem. 13, 113-117

\section{STRESZCZENIE}

Wstępne badania obrazu mikrobiologicznego przewodu pokarmowego kurcząt brojlerów otrzymujących dietę bez i z antybiotykiem

W jelicie cienkim kurcząt brojlerów dominowały bakterie Lactobacillus spp., Escherichia coli i Streptococcus spp. W treści jelitowej kurcząt grup doświadczalnych (otrzyjmujących mannan, bakterie kwasu mlekowego lub kwasy organiczne) więcej było bakterii Enterococcus spp., Escherichia coli, Streptococcus spp. niż u kurcząt otrzymujących antybiotyk. W jelicie ślepym przeważały bakterie Escherichia coli, Lactobacillus spp. i Enterococcus spp. W jelicie ślepym ptaków otrzymujących dodatek antybiotyku w diecie, w przeciwieństwie do pozostałych grup, nie stwierdzono bakterii Clostridium spp., w tym Clostridium perfringens. Rodzaj kwasu (fumarowy vs mrówkowy) nie miał wpływu na skład mikroflory jelitowej kurcząt. 